Research article

\title{
Removal and monitoring acetaminophen-contaminated hospital wastewater by vertical flow constructed wetland and peroxidase enzymes
}

\author{
Hoang Nhat Phong Vo ${ }^{\mathrm{a}, \mathrm{d}, *}$, Thammarat Koottatep ${ }^{\mathrm{a}}$, Saroj Kumar Chapagain ${ }^{\mathrm{b}}$, \\ Atitaya Panuvatvanich $^{\mathrm{a}}$, Chongrak Polprasert ${ }^{\mathrm{c}}$, Thi Minh Hong Nguyen ${ }^{\mathrm{a}}$, Chawalit Chaiwong ${ }^{\mathrm{a}}$, \\ Ngoc Luong Nguyen ${ }^{\mathrm{d}}$ \\ ${ }^{a}$ Environmental Engineering and Management, Asian Institute of Technology (AIT), P.O.Box 4, Klong Luang, Pathumthani, 12120, Thailand \\ ${ }^{\mathrm{b}}$ United Nations University, Institute for the Advanced Study of Sustainability (UNU-IAS), 5-53-70, Shibuya-Ku, Tokyo, 150-8925, Japan \\ ${ }^{\mathrm{c}}$ Faculty of Engineering, Thammasat University, Pathumthani, 12120, Thailand \\ ${ }^{\mathrm{d}}$ Centre for Technology in Water and Wastewater, School of Civil and Environmental Engineering, University of Technology Sydney, Sydney, NSW, 2007, Australia
}

\section{A R T I C L E I N F O}

\section{Keywords:}

Acetaminophen

Constructed wetland

Hospital wastewater

Nutrient

Peroxidase enzyme

Micro-pollutant

\begin{abstract}
A B S T R A C T
Hospital wastewater contains acetaminophen (ACT) and nutrient, which need adequate removal and monitoring to prevent impact to environment and community. This study developed a pilot scale vertical flow constructed wetland (CW) to (1) remove high-dose ACT and pollutants in hospital wastewater and (2) identify the correlation of peroxidase enzyme extruded by Scirpus validus and pollutants removal efficiency. By that correlation, a lowcost method to monitor pollutants removal was drawn. Plants, such as Scirpus validus, generated peroxidase enzymes to alleviate pollutants' stress. Results showed that the CW removed 3.5 to 6 logs of initial concentration $10 \mathrm{mg} \mathrm{ACT/L}$ to a recommended level for drinking water. The CW eliminated COD, TKN and TP efficiently, meeting the wastewater discharged standards of Thailand and Vietnam. By various multivariable regression models, concentrations of ACT in CW effluent and enzymes in $S$. validus exhibited a significant correlation $\left(p<0.01, \mathrm{R}^{2}=68.3 \%\right)$. These findings suggested that (i) vertical flow CW could remove high-dose ACT and nutrient and (ii) peroxidase enzymes generated in $S$. validus, such as soluble and covalent ones, could track ACT removal efficiency. This would help to reduce facilities and analytical cost of micro-pollutants.
\end{abstract}

\section{Introduction}

Hospital wastewater contains various pollutants such as micro-pollutants and nutrient. Micro-pollutants can accumulate in the human body via contaminated drinking water and food; then posing a health risk to community. Among micro-pollutants, acetaminophen (ACT) emerges regularly in hospital wastewater because it is one of the most prescribed drugs recently (Phong Vo et al., 2019). In France and Spain, ACT was consumed at highest rates of 54.3 and $22.6 \mathrm{~g} / \mathrm{y}$. inhabitant, respectively (Ortiz de García et al., 2013). In 2004, ACT was the most prescribed medication in Taiwan of 600 million doses (Lin and Tsai, 2009). It is detected frequently in hospital wastewater treatment plants across Asia, Europe and America with notable concentrations (50-400 $\mu \mathrm{g} / \mathrm{L}$ ) and frequency (100\%) (Kosma et al., 2010; Kumar et al., 2019). This concentration is much higher than the recommended level for drinking water (71 ng/L) (Vulliet and Cren-Olivé, 2011). Nutrient is another pollutant of concern in hospital wastewater. High concentration of nutrient can cause eutrophication in water reservoir. Critically, hospital wastewater needs adequate treatment to remove ACT and nutrient before discharging to water reservoir.

Constructed wetland (CW) can resolve the pollutants induced by hospital wastewater. This technology functions by infusion of biological, physical and chemical processes. Those processes co-occur in CW and enhance pollutants removal extensively (Hickey et al., 2018; Zhang et al., 2014a). CW also certifies a low-cost technology for decentralized wastewater treatment system. Its operation and maintenance cost 0.014-0.0134 \$USD $/ \mathrm{m}^{3}$ wastewater compared with $0.1151-0.2465$ $\$ \mathrm{USD} / \mathrm{m}^{3}$ wastewater of conventional system (Arias and Brown, 2009; Chen et al., 2008). Practically, CW includes vertical and horizontal flow configuration. The vertical flow CW is more competent for hospital wastewater treatment because it possesses advanced properties. For example, the vertical flow CW conditions nitrifying ammonia and oxidation process effectively (Vymazal, 2011). In terms of footprint, the vertical flow CW uses $1-3 \mathrm{~m}^{2}$ /population equivalent, whereas the

\footnotetext{
${ }^{*}$ Corresponding author. Environmental Engineering and Management, Asian Institute of Technology (AIT), P.O.Box 4, Klong Luang, Pathumthani, 12120, Thailand.

E-mail address: phongvobk@gmail.com (H.N.P. Vo).
} 
horizontal flow CW requires $5 \mathrm{~m}^{2} /$ population equivalent (Vymazal, 2011).

In CW, a plant can uptake and remove pollutants. Pollutants accumulate in the plant's body, causing stress and altering the plant's biochemical system. This induces plant to generate reactive oxygen species (e.g. $\mathrm{H}_{2} \mathrm{O}_{2}$ ) to signal the endangered situation (Zandalinas and Mittler, 2018). However, the overproduction of reactive oxygen species can damage the macromolecules such as nucleic acids, proteins and lipids. To alleviate the situation, the plant triggers the antioxidant system (Jaskulak et al., 2018). The antioxidant system includes peroxidase enzymes of soluble (SP), ionical (IP) and covalent (CP) forms that localized as soluble, ionical and covalent bound to cell wall. SP enzyme presents in apoplastic fluid and penetrates through cell walls. IP enzyme exists in hydrophobic and ionic conditions with polysaccharides and proteins while $\mathrm{CP}$ enzyme cross-links with the cell wall components by covalent bonds. Peroxidase enzymes are catalysts for $\mathrm{H}_{2} \mathrm{O}_{2}$ to oxidize organic compounds and therefore reduce stress to plant. The peroxidase undergoes a cyclic reaction as it reacted the phenolic compound (Eqs. (1)-(3)). The peroxidase induces reactions in its original form, then oxidized by $\mathrm{H}_{2} \mathrm{O}_{2}$ to form the intermediate (Peroxidase ${ }_{1}$ ). The intermediate E1 oxidizes phenolic substances $(\mathrm{PhOH})$ to free racial $(\mathrm{PhO})$ and next intermediate (Peroxidase ${ }_{2}$ ). The intermediate Peroxidase ${ }_{2}$ continually oxidizes phenolic compounds and returns to the native form, ending the cycle.

Peroxidase $+\mathrm{H}_{2} \mathrm{O}_{2} \rightarrow$ Peroxidase $_{1}+\mathrm{H}_{2} \mathrm{O}$

Peroxidase $_{1}+\mathrm{PhOH}^{\prime} \rightarrow$ Peroxidase $_{2}+\mathrm{PhO}$

Peroxidase $_{2}+\mathrm{PhOH}^{\prime} \rightarrow$ Peroxidase $+\mathrm{PhO}+\mathrm{H}_{2} \mathrm{O}$

Although CW is used widely for wastewater treatment, research gaps remain in the application of vertical flow CWs. First, the actual ACT-removal capacity of vertical flow $\mathrm{CW}$ is underestimated in previous studies experimented with a low-range ACT concentration (i.e. less than mg/L) (Ávila et al., 2014; Petrie et al., 2018; Yi et al., 2017). Still, the quantitative correlation of peroxidase enzymes and pollutants in wastewater is not considered. Several studies report that peroxidase involves in the phenolic compounds degradation process (i.e., ACT, diclofenac, bisphenol A). For instance, peroxidase and glycosyltransferase enzymes are proved as catalysts for clofibric acid degradation, but their correlation of peroxidase enzyme and the pollutants removal is not adequately quantified (Dordio et al., 2009; Huber et al., 2012, 2016). Herein, to explore the correlation, we hypothesize that pollutants of hospital wastewater, including ACT, correlate with $\mathrm{H}_{2} \mathrm{O}_{2}$, SP, IP and CP enzymes as first-order linear model. By establishing that correlation, peroxidase enzymes can track pollutants removal efficiencies of CW. Hence, analytical cost of pollutants is saved extensively.

To unveil those gaps, the objectives of this work are to (1) investigate high-dose ACT removal $(10 \mathrm{mg} / \mathrm{L})$ and (2) monitor pollutants removal efficiencies by peroxidase enzymes in a pilot scale vertical flow CW.

\section{Materials and methods}

\subsection{A vertical flow $C W$ and its operation}

The pilot scale vertical flow CW was constructed using respective length, width and height of $1.5,0.6$ and $0.6 \mathrm{~m}$. The media bed contained sand, pea gravel and gravel with respective height of 0.1, 0.2 and $0.4 \mathrm{~m}$ from top to bottom. The porosities of sand, pea gravel and gravel bed were different in $d_{10}$ and $d_{60}$ values (Table S1). These differences made the filtration bed with pore size from small to large from top to bottom. The bottom of CW was sloped 1\% for drainage. The Scirpus validus, which grew naturally in local wetlands, was selected for this CW. It was planted in the CW for three weeks to adapt and grow in new environment.
The CW was operated continuously for $65 \mathrm{~d}$ using flow rate of $75-85 \mathrm{~L} / \mathrm{d}$, coupling hydraulic retention time of $5 \mathrm{~d}$. The CW was fed in which the water surface was $0.05 \mathrm{~m}$ below the sand surface. Wastewater for this experiment was influent of a hospital's wastewater treatment plant (Pathumthani, Thailand). The concentrations of suspended solid (SS), chemical oxygen demand (COD), $\mathrm{NH}_{4}{ }^{+}-\mathrm{N}, \mathrm{NO}_{3}{ }^{-}-\mathrm{N}$, total Kjeldahl nitrogen (TKN) and total phosphorus (TP) in wastewater were $\quad 500 \pm 236.8, \quad 352.7 \pm 164.1, \quad 25 \pm 6.4, \quad 1.0 \pm 0.6$, $36.6 \pm 12.6,7.9 \pm 4.3 \mathrm{mg} / \mathrm{L}$, respectively $(\mathrm{n}=4)$. Wastewater was stored in $1 \mathrm{~m}^{3}$ tank and mixed continuously during the feeding.

ACT concentration in wastewater was stable at $2.7 \pm 0.83 \mu \mathrm{g} / \mathrm{L}$ $(\mathrm{n}=4)$. To evaluate ACT removal efficiency by the CW, ACT concentration was increased to $10 \mathrm{mg} / \mathrm{L}$ by adding a stock solution (Sigma Aldrich, Thailand).

\subsection{Methods}

\subsubsection{Plant and wastewater sampling}

The $S$. validus plant and wastewater samples were collected every $5 \mathrm{~d}$. For plant samples, root biomass was conserved by removing sand around the plant and gently pulling from CW. All collected plants were rinsed under deionized water for $2 \mathrm{~min}$, air dry in room temperature and stored at $4{ }^{\circ} \mathrm{C}$ prior to analysis. The wastewater samples were collected via the bottom valve of CW. The samples were preserved using Ethylenediaminetetraacetic acid (EDTA) to prevent microbial activity until analysis.

\subsubsection{Acetaminophen analysis}

ACT analysis was described in our previous work (Phong et al., 2016). In brief, solid-phase extraction was performed on Oasis HLB sorbent cartridges. The cartridges were preconditioned with $4 \mathrm{ml}$ of methanol and $6 \mathrm{ml}$ of distilled water $(\mathrm{pH}=3.5)$. The water samples were percolated through the cartridges at flow rate of $5 \mathrm{ml} / \mathrm{min}$. To analyse ACT, the cartridges were eluted with $6 \mathrm{ml}$ of methanol into $10 \mathrm{ml}$ test tube. Methanol was evaporated under a gentle nitrogen stream at $37^{\circ} \mathrm{C}$ and reconstituted with acidified ultra-pure water $(0.01 \%$ formic acid: $=9: 1)$ to final volume of $1 \mathrm{ml}$. Final extracts were stored in $2 \mathrm{ml}$ glass vials and analysed by HPLC-MS/MS (Shimadzu, 8060).

\subsubsection{Hydrogen peroxide analysis}

Hydrogen peroxide $\left(\mathrm{H}_{2} \mathrm{O}_{2}\right)$ was analysed as described by Phong et al. (2016). Plant samples were homogenized by using $1.5 \mathrm{~g}$ (wet weight), ground in mortar with liquid nitrogen. Then, they were suspended in $5 \mathrm{ml}$ of $0.2 \mathrm{M}$ perchloric acid and centrifuged at $1200 \mathrm{~g}, 4^{\circ} \mathrm{C}$ for $5 \mathrm{~min}$. The received supernatants were neutralized by $4 \mathrm{M} \mathrm{KOH}$ to $\mathrm{pH}$ 7.5. The total volume of each sample was $10 \mathrm{ml}$. The sample was centrifuged at $3000 \mathrm{~g}, 4^{\circ} \mathrm{C}$ in $15 \mathrm{~min}$ to remove insoluble potassium perchlorate. Subsequently, $800 \mu \mathrm{l}$ of aliquot was applied to $0.12 \mathrm{~g}$ anion exchange resin column (AG 1-X2, Bio-Rad). The column was washed by $3.2 \mathrm{ml}$ distilled water before collected $1 \mathrm{ml}$ of elute.

In spectrophotometer cuvette, the elute was added $400 \mu \mathrm{l}$ of $12.5 \mathrm{mM}$ 3-dimethylaminobenzoic acid, $80 \mu \mathrm{l}$ of $1.3 \mathrm{mM}$ 3-methyl-2benzothiazolinone hydrazone and $20 \mu \mathrm{l}$ horseradish peroxidase, respectively. The reaction mixture was incubated at $25^{\circ} \mathrm{C}$ for $5 \mathrm{~min}$. Then the reaction was stopped by cooling in ice bath for $15 \mathrm{~min}$. After $10 \mathrm{~min}$, the absorbance was read at $590 \mathrm{~nm}$ and compared with calibration curve for result (Table S2).

\subsubsection{Peroxidase analysis}

Peroxidase fractions were extracted by the following steps. Initially, $0.5 \mathrm{~g}$ of plant tissue was ground using $4 \mathrm{ml}$ of $50 \mathrm{mM}$ Tris Maleate $(\mathrm{pH}$ 6.0). The solution was transferred to centrifuge tube, kept immediately in triturated ice and centrifuged at $2{ }^{\circ} \mathrm{C}, 1000 \mathrm{~g}$ in $10 \mathrm{~min}$. The supernatant was collected stored in freezer at $-80^{\circ} \mathrm{C}$. This fraction was for measuring the SP enzyme. The precipitate was kept for extraction of IP 
and $\mathrm{CP}$ enzymes.

Of the SP enzyme, $50 \mu \mathrm{l}$ of plant extract (supernatant from the above step) and the chemicals were added in cuvette consisting of $500 \mu \mathrm{l}$ of $30 \mathrm{mM}$ hydrogen peroxide, $500 \mu \mathrm{l}$ of $168 \mathrm{mM}$ guaiacol, $1.95 \mathrm{ml}$ of $40 \mathrm{mM}$ tris maleate buffer $\mathrm{pH} 6.0$, respectively. The cuvette was read at absorbance $470 \mathrm{~nm}$.

SP enzyme activity $=\mathrm{Abs}_{60}-\mathrm{Abs}_{0}$

Where.

$\mathrm{Abs}_{60}$ : absorbance at time $60 \mathrm{~s}$

$\mathrm{Abs}_{0}$ : absorbance at time 0

The IP enzyme was extracted from the precipitate of SP enzyme. The precipitate was incubated by $2 \mathrm{ml}$ of $0.2 \mathrm{M} \mathrm{CaCl}_{2}$ in room temperature for $2 \mathrm{~h}$. The mixture was centrifuged at $2{ }^{\circ} \mathrm{C}, 1800 \mathrm{~g}$ in $20 \mathrm{~min}$.

The CP enzyme was extracted from the precipitate of IP's extraction process. The precipitate was added $1 \mathrm{ml}$ of triz maleate buffer $40 \mathrm{mM}$. Then, it was centrifuged at $2{ }^{\circ} \mathrm{C}, 1800 \mathrm{~g}$ in $20 \mathrm{~min}$. The supernatant was collected for CP. The measurement of CP and IP enzyme activity was similar to the procedure of SP's analysis. One unit of peroxidase is defined as the amount of enzyme that reduces $1.0 \mathrm{mmol}$ of $\mathrm{H}_{2} \mathrm{O}_{2}$ per minute at $37^{\circ} \mathrm{C}$.

\subsubsection{Analysis of other parameters}

The other parameters including suspended solid (SS), chemical oxygen demand (COD), total kjeldahl nitrogen (TKN), ammonia nitrogen $\left(\mathrm{NH}_{4}{ }^{+}-\mathrm{N}\right)$, nitrate nitrogen $\left(\mathrm{NO}_{3}{ }^{-}-\mathrm{N}\right)$, total phosphorus (TP) were analysed according to the Standard Method (APHA, 2005).

\subsubsection{First-order kinetic modelling}

By assuming that CW was a continuous stirred-tank reactor, the first-order kinetic model was used for ACT removal (Eq. (5)). The volumetric decay rate constant $\left(\mathrm{k}_{\mathrm{v}}\right)$ was estimated based on inlet-outlet data of the CW. The first-order reaction equation was:

$\ln \left(\frac{C_{\text {in }}}{C_{\text {out }}}\right)=K_{v} \times t$

where.

$\mathrm{C}_{\text {out }}$ : pollutant concentration in the effluent $(\mu \mathrm{g} / \mathrm{L})$

$\mathrm{C}_{\text {in }}$ : pollutant concentration in the influent $(\mu \mathrm{g} / \mathrm{L})$

$\mathrm{k}_{\mathrm{v}}$ : volumetric decay rate constant $(/ \mathrm{d})$

$\mathrm{t}$ : time (d)

\subsubsection{Multi-variable regression}

The multi-variable regression analysis was employed for establishing the correlation of enzymes and pollutants concentrations in effluent of CW. Firstly, the Lindeman, Merenda and Gold analysis was conducted for evaluating the importance of variables and significance of models. Only the respective models and variables possessed significant $\mathrm{R}^{2}$ and contribution values would be processed. Then, the multivariable regression methods, including "all possible subsets", "forward selection" and "backward elimination", were implemented to establish models.

The multivariable regression model is assumed as the following:

$y=\alpha+\beta_{1} X_{1}+\beta_{2} X_{2}+\beta_{3} X_{3}+\cdots+\beta_{\mathrm{n}} X_{\mathrm{n}}$

where.

$\mathrm{y}$ : responsible variable $\left(\mathrm{C}_{\mathrm{X} . \mathrm{E}}\right)$

$\mathrm{x}_{\mathrm{i}}$ : predictor variables $\left(\mathrm{C}_{\mathrm{X} . \mathrm{R}}, \mathrm{C}_{\mathrm{X} . \mathrm{S}}\right)$

$\mathrm{C}_{\mathrm{X} . \mathrm{E}}$ : concentration of pollutants $\mathrm{X}$, including ACT, $\mathrm{COD}, \mathrm{NO}_{3}{ }^{-}-\mathrm{N}$ and TP, in the effluent of CW.

$\mathrm{C}_{\mathrm{X} . \mathrm{R}}, \mathrm{C}_{\mathrm{X} . \mathrm{S}}$ : concentration of enzymes X, including $\mathrm{H}_{2} \mathrm{O}_{2}, \mathrm{SP}, \mathrm{CP}$ and
IP in the root and shoot of plant, respectively.

The R software was applied for multivariable regression using the Relaimpo and Mass package. The Relaimpo package was for Lindeman, Merenda and Gold analysis, while Mass was to operate the "all possible subsets", "forward selection" and "backward elimination" methods. The code was provided in appendix.

\subsection{Statistical analysis}

The analyses of variance (ANOVA) were used for statistical analysis. The repeated measures ANOVA were applied to investigate the significant difference of enzymes in root and shoot. Concentrations and removal efficiencies were presented as mean \pm standard deviation. All the statistical analyses were performed by $\mathrm{R}$ software. The statistical differences of results were compared by using means' values with $95 \%$ confidence level.

\section{Results and discussions}

\subsection{Acetaminophen removal by constructed wetland}

By employing $10 \mathrm{mg} \mathrm{ACT/L} \mathrm{concentration} \mathrm{in} \mathrm{the} \mathrm{influent,} \mathrm{we} \mathrm{found}$ that this vertical flow CW reduced 3.5 to $6 \log$ ACT. The ACT concentration in CW effluent decreased to below $0.4 \mu \mathrm{g} / \mathrm{L}$ and stayed consistently from day 15th-25th (Fig. 1a). This concentration was safe to aquatic living given the standard $\mathrm{EC}_{50}$ concentration - a parameter for assessing toxicity - was $50 \mathrm{mg} / \mathrm{L}$ (Kim et al., 2007). It also complied with recommendation for drinking water $(71 \mathrm{ng} / \mathrm{L}$ ) (Vulliet and CrenOlivé, 2011). After $45 \mathrm{~d}$, ACT concentration in CW effluent was less than the suggested level for drinking water. Therefore, this vertical flow CW compromised high-dose ACT and removed it effectively.

A removal kinetic and half-life ACT degradation were analysed to quantify the technical performance of CW. As a result, the ACT removal kinetic of CW fitted highly to first order $\left(\mathrm{R}^{2}=0.89\right)$ and half-life degradation was $13.6 \mathrm{~d}\left(=\frac{1}{k_{v}}=\frac{1}{0.073}\right)$ (Fig. 1b). The half-life degradation values were higher than previous reports, which documented from 0.3 to $2.1 \mathrm{~d}$ (Ranieri et al., 2011; Yamamoto et al., 2009). The discrepancy was attributed to the applied wastewater sources and initial ACT concentrations. Those authors used distilled and river waters, which unanticipated the side effects of other factors in hospital wastewater (e.g. high suspended solid level). In addition, the half-life of ACT degradation depended largely on its initial concentration such as $10 \mathrm{mg} / \mathrm{L}$ in this study compared with 0.7-100 $\mu \mathrm{g} / \mathrm{L}$ (Ranieri et al., 2011; Yamamoto et al., 2009).

This vertical flow CW could eliminate high-dose ACT as it was regulated concurrently by various mechanisms, encompassing plant uptake, biodegradation and adsorption (Phong et al., 2016). Plant uptake advanced pollutants removal in CW. S. validus could uptake 16.8-58.1 $\mu \mathrm{g} \mathrm{ACT/g} \mathrm{fresh} \mathrm{weight.d} \mathrm{and} \mathrm{degrade} \mathrm{ACT} \mathrm{to} \mathrm{non-toxic} \mathrm{me-}$ tabolites (Phong et al., 2016). For example, ACT and its metabolites were detected in plant's tissue of Armoracia rusticana and Brassica juncea (Bartha et al., 2010; Huber et al., 2009). The uptaking process impaired $70 \%$ of $1 \mathrm{mM}$ ACT dose in $3 \mathrm{~h}$. After $6 \mathrm{~h}, 18 \%$ paracetamol, $64 \%$ paracetamol-glucoside, $17 \%$ paracetamol glutathione and $1 \%$ of cysteine conjugate were detected in plant tissue (Huber et al., 2009). Biodegradation was a well-established removal process because aerobic and anaerobic bacteria in CW could assimilate pollutants. For instance, Pseudomonas spp. and Bacillus spp accumulated 1.0-4.1 mg ACT/ $\mathrm{g}_{\text {biomass. }}$. (Baratpour and Moussavi, 2018). Microorganism could be inhibited by high-dose ACT - 50-1000 mg/L (Alvarino et al., 2014); nevertheless those concentrations unlikely existed in wastewater.

For adsorption, it removed ACT ineffectively since ACT was a low hydrophobic substance $\left(\mathrm{K}_{\mathrm{d}}<3\right)$ (Zhang et al., 2014a). Adsorption also could not compete with biodegradation. It accounted only 30\% ACT 

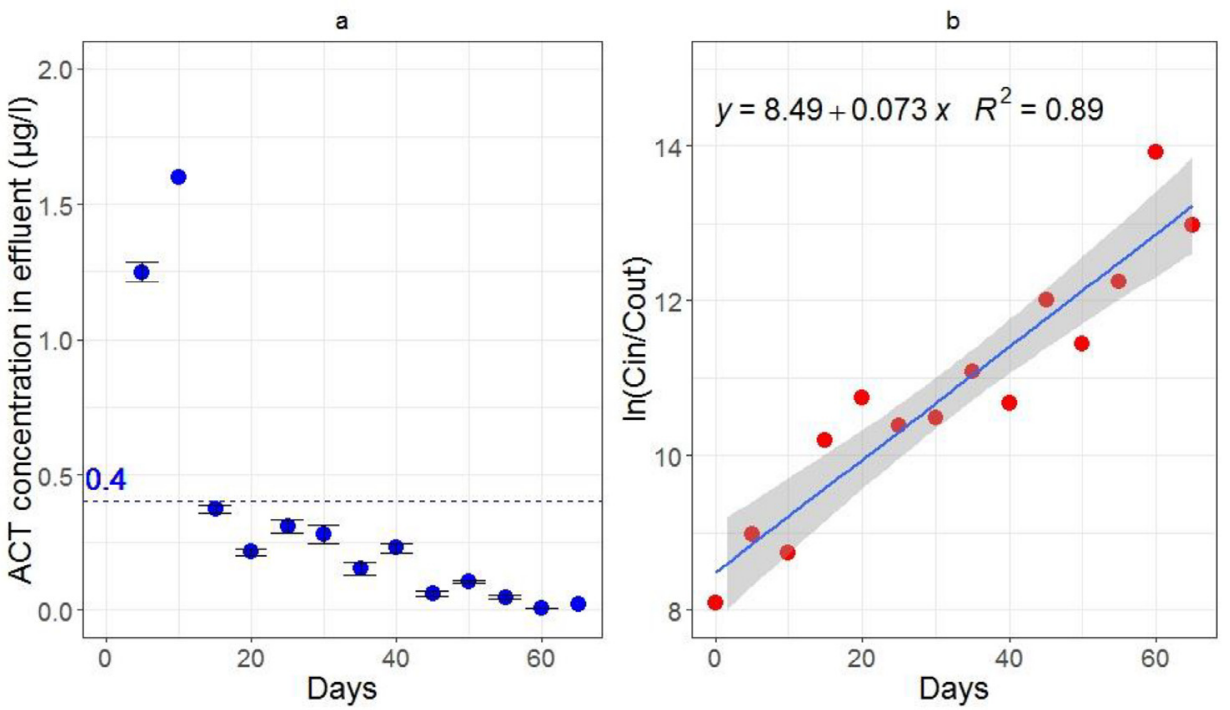

Fig. 1. ACT concentration in CW effluent (a), kinetic of ACT removal in CW (b).

removal in the co-processes of adsorption and biodegradation (Lin et al., 2010). To improve ACT adsorption efficiency, we suggested using light expanded clay aggregates media, so-called LECA, as this material contains alkaline of oxides and carbonates (Machado et al., 2017). They would increase adsorption efficiency by enhancing electrostatic interaction of LECA's surface and pollutants.

This vertical flow CW proceeded horizontal flow CW in ACT removal (Table 1). Typically, horizontal flow CW removed beyond $99 \%$ ACT load; however ACT initial concentration was considerably low at $750 \mathrm{ng} / \mathrm{L}$ and flow rate at $1 \mathrm{~m}^{3} / \mathrm{d}$ that much less than this work (Ranieri et al., 2011). In another study, it removed $45 \%$ ACT operating with $30 \mathrm{ng}$ ACT/L in influent and achieving $16 \mathrm{ng}$ ACT/L in effluent (Verlicchi et al., 2013). Similarly, horizontal CW used various substrates (e.g., steel slag, gravel) and removed only 65\% ACT of initial concentration $273 \mathrm{ng} / \mathrm{L}$ (Petrie et al., 2018). For the reason, horizontal flow CW just exploited part of its media and plant bed because wastewater was fed on side, rather than the whole surface like vertical flow CW. This vertical flow CW removed high-dose ACT better also thanks to S. validus. This plant could uptake $80 \%$ micro-pollutants - clofibric acid - at notable dose $2 \mathrm{mg} / \mathrm{L}$ (Zhang et al., 2013). Other plants, such as Typha spp., removed only $50 \%$ clofibric acid at lower dose $20 \mu \mathrm{g} / \mathrm{L}$ (Dordio et al., 2009). Although vertical flow CW displayed a distinct ACT removal efficiency in this work, horizontal flow CW also needed studies with high-dose ACT for a fair comparison.

\subsection{Nutrient removal in constructed wetland}

The vertical flow CW effectively removed nutrients (Table 2). It diminished sufficiently $80 \% \mathrm{SS}, \mathrm{NH}_{4}{ }^{+}-\mathrm{N}$ and COD. The process also reduced at least $65 \% \mathrm{TKN}$ and TP. Although the system unlikely removed TN and TS as that much; nevertheless, TSS, $\mathrm{NH}_{4}{ }^{+}-\mathrm{N}, \mathrm{NO}_{3}{ }^{-}-\mathrm{N}$, TKN, TN, TP, COD concentrations in CW effluent complied with discharged standards for hospital wastewater in developing countries: Vietnam (MonRe Vietnam, 2010) and Thailand (MonRe Thailand, 2005) (Table S3).

In this study, vertical flow CW removed TN moderately, less than $22 \%$, because of insufficient denitrification (Sgroi et al., 2018). In essence, the horizontal flow CW conditioned denitrification better than vertical flow pattern. For example, horizontal flow CW removed above $50 \%$ TN of initial concentration 50-200 mg/L (Nguyen et al., 2018). Our results agreed with previous findings. The vertical flow CW could handle $35-52 \%$ TN while horizontal flow one removed 69\% TN (Sgroi et al., 2018). Similarly, Kahl et al. (2017) reported that vertical flow CW treat $45-56 \%$ TN compared with $52-72 \%$ TN of horizontal flow CW (Kahl et al., 2017). To increase TN removal in this study, we proposed applying consecutive vertical flow CWs or vertical-horizontal hybrid CWs. If spacing was limited, recirculating 50\% effluent would shift TN removal 66\% (Ávila et al., 2017).

For solid pollutant, high TS concentration remained in the effluent because of dissolved solid in hospital wastewater (Carraro et al., 2016). Those dissolved solids included salts, solvents and hydrocarbons. In CW, biological process performed poorly at high-dose TDS and plant uptake demonstrated a fair removal efficiency, which exclude $21 \%$ of $2500 \mathrm{mg}$ TDS/L (Valipour et al., 2014). Hence, we suggest using advanced oxidation process to diminish high-dose TDS, but it would generate extra cost. Otherwise, LECA media was an alternative to augment both TN and dissolved solids removal (Liu et al., 2014; Machado et al., 2017). This media was highly useful for removing water-soluble compounds in hospital wastewater, such as furosemide, benzene, alcohol and acid.

The rising concern was whether other pollutants influenced ACT removal efficiency in CW. In practice, the bulk nutrients would nurture plant and microbial community growing up and augment ACT removal efficiency accordingly (Zhang et al., 2014a). Rhizosphere and microbial community played an important role in creating the aerobic environment and uptaking ACT. The suspended solid concentration of wastewater also partly adsorbed ACT (Zhang et al., 2014a). Hence, ACT removal received indirect benefits from other pollutants of hospital wastewater.

\subsection{Hydrogen peroxide enzyme response to pollutants stress}

The plant produces $\mathrm{H}_{2} \mathrm{O}_{2}$ enzyme in apoplast, chloroplasts, mitochondria. The invasive targets of $\mathrm{H}_{2} \mathrm{O}_{2}$ are nucleic acids, proteins and lipids (Zandalinas and Mittler, 2018). Environmental stresses, such as excess light, UV, drought, high temperature and pollutants trigger $\mathrm{H}_{2} \mathrm{O}_{2}$ production by various signalling pathways. In this study, we recorded $\mathrm{H}_{2} \mathrm{O}_{2}$ concentrations in shoot and root of $S$. validus, stressed by hospital wastewater containing ACT and nutrient, to elucidate its response.

After exposure to hospital wastewater, the shoot of $S$. validus generated $636 \pm 130.1 \mathrm{nmol} \mathrm{H}_{2} \mathrm{O}_{2} / \mathrm{g} \mathrm{FW}(\mathrm{n}=14)$ while the root produced $426.8 \pm 69.6 \mathrm{nmol} \mathrm{H}_{2} \mathrm{O}_{2} / \mathrm{g} \mathrm{FW}\left(\mathrm{n}=14\right.$ ) (Fig. 2a). $\mathrm{H}_{2} \mathrm{O}_{2}$ concentration of the shoot was higher because the plant translocated ACT to the shoot after uptaking it. The shoot would degrade ACT to metabolites, such as glucoside, glutathione and cysteine conjugate (Huber et al., 2009). For small-dose micro-pollutants less than $100 \mu \mathrm{g} / \mathrm{L}$, the 
Table 2

Removal of other pollutants by the vertical flow $\mathrm{CW}$.

\begin{tabular}{llll}
$\begin{array}{l}\text { Parameters } \\
(\mathrm{mg} / \mathrm{L})\end{array}$ & $\begin{array}{l}\text { Influent } \\
\text { concentration }(n=4)\end{array}$ & $\begin{array}{l}\text { Effluent } \\
\text { concentration } \\
(n=13)\end{array}$ & $\begin{array}{l}\text { Removal } \\
\text { efficiency (\%) }\end{array}$ \\
\hline $\mathrm{TS}$ & $5745.0 \pm 1076.8$ & $6297.9 \pm 1294.7$ & - \\
$\mathrm{TSS}$ & $500 \pm 236.8$ & $82.8 \pm 46.9$ & $81.1 \pm 2.8$ \\
$\mathrm{TDS}$ & $5378.3 \pm 1191.5$ & $6115 \pm 1269.3$ & - \\
$\mathrm{NH}_{4}-\mathrm{N}$ & $25.0 \pm 6.4$ & $1.3 \pm 2.3$ & $94.8 \pm 11.9$ \\
$\mathrm{TKN}$ & $36.6 \pm 12.6$ & $12.7 \pm 6.9$ & $65.3 \pm 11.1$ \\
$\mathrm{NO}_{3 \bar{N}}$ & $1.0 \pm 0.6$ & $12.2 \pm 8.1$ & - \\
$\mathrm{COD}$ & $52.7 \pm 164.1$ & $42.1 \pm 23.8$ & $88.1 \pm 33.1$ \\
$\mathrm{TN}$ & $42.3 \pm 15.5$ & $32.8 \pm 20.3$ & $22.5 \pm 31.9$ \\
$\mathrm{TP}$ & $7.9 \pm 4.3$ & $2.6 \pm 0.8$ & $67.1 \pm 15.6$ \\
\end{tabular}

root could degrade them totally; thus, $\mathrm{H}_{2} \mathrm{O}_{2}$ concentration in the root exceeded the shoot (Sun et al., 2018). One strategy to alleviate the stress was to translocate pollutants from root to shoot but it depended on the originality of pollutants. For example, $\mathrm{Pb}$ is a heavy metal possessing high atomic number and its mobility is the lowest amongst all heavy metals. Thus, $\mathrm{Pb}$ is mostly accumulated in the root than the shoot (Gupta et al., 2013). For ACT, it can be seen it was an easy-translocating compound for plant. It explained for the competitive $\mathrm{H}_{2} \mathrm{O}_{2}$ level in shoot compared to root in both hydroponic and hospital wastewater (Phong et al., 2016).

In hydroponic conditions, shoot and root produced $318.5 \pm 64.5 \mathrm{nmoL} / \mathrm{g} \mathrm{FW}$ and $442.2 \pm 48.6 \mathrm{nmoL} / \mathrm{g} \mathrm{FW}$, respectively (Phong et al., 2016). They were a half to equivalent compared with $\mathrm{H}_{2} \mathrm{O}_{2}$ concentration experimented with hospital wastewater. Hospital wastewater contained high-dose ACT and other pollutants (e.g., nitrogen, carbon, phosphorus) that would shift $\mathrm{H}_{2} \mathrm{O}_{2}$ concentration consequently. ACT is a toxic organic substance rather than a nutrient. Its $\mathrm{EC}_{50}$ dose to macrophytes was documented at $450 \mathrm{mg} / \mathrm{L}$ (Nunes et al., 2014). As known, plant produced $\mathrm{H}_{2} \mathrm{O}_{2}$ by various factors, not only ACT; however, comparing the studies of artificial (low-dose ACT) and hospital wastewater (high-dose ACT), we indicated that the stress of ACT to plant dominated other pollutants because, due to the presence of ACT, $\mathrm{H}_{2} \mathrm{O}_{2}$ concentration in artificial wastewater accounted from a half to similar level $\mathrm{H}_{2} \mathrm{O}_{2}$ in hospital wastewater.

\subsection{Peroxidase enzyme response to pollutants stress}

Plant can produce several enzyme types such as superoxide dismutase, catalase and peroxidase. Peroxidase is special enzyme of the plant as it involves directly to the degradation of phenolic compounds by catalysing or oxidizing them, supporting by $\mathrm{H}_{2} \mathrm{O}_{2}$. Peroxidase enzyme is so-called ROS-consuming and ROS-generating as co-function. Other enzymes did not participate in the phenolic compound degradation process. For example, the superoxide dismutase scavenges the dismutation of the superoxide radical to ordinary molecular oxygen or hydrogen peroxide, and the catalase decomposes $\mathrm{H}_{2} \mathrm{O}_{2}$ to water and oxygen. By those functions, peroxidase interrelates micropollutants degradation process and it includes ACT (Huber et al., 2012, 2016). Peroxidase is the most active and dynamic one against micropollutants. Recent proteomic studies showed that peroxidase accounts half of the oxido-reductase class in plant. Oxido-reductase is the main oxidative class functioning the organic compounds' degradation. Therefore, peroxidase participates in ACT degradation process competitively than other enzymes. Under normal condition, peroxidase enzymes engage in lignin and phenolic polymers synthesis. Upon suffering from $\mathrm{H}_{2} \mathrm{O}_{2}$ stress, peroxidase enzymes would catalyse the degradation of organic substances and $\mathrm{H}_{2} \mathrm{O}_{2}$ and alleviate the stress (Eq. (1)).

From Fig. 2b, c, d, the breakthrough points of all peroxidase enzymes were recorded since day 25 th. Concentration of enzymes in the root shifted steadily and ACT concentration in effluent dropped below $0.4 \mu \mathrm{g} / \mathrm{L}$. One indicated that all peroxidase enzymes started involving in 


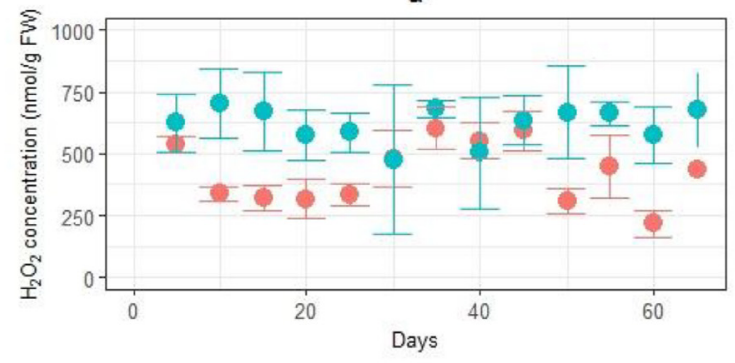

c

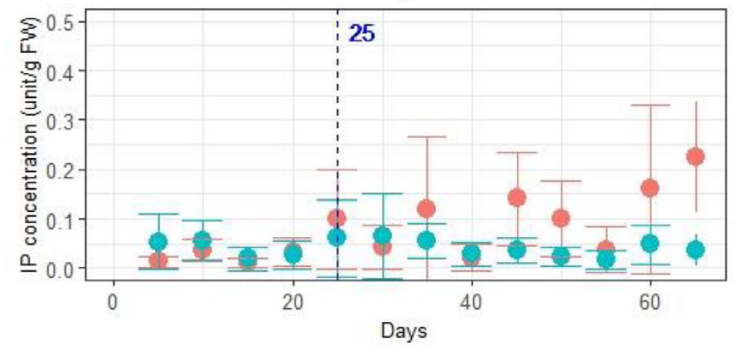

b

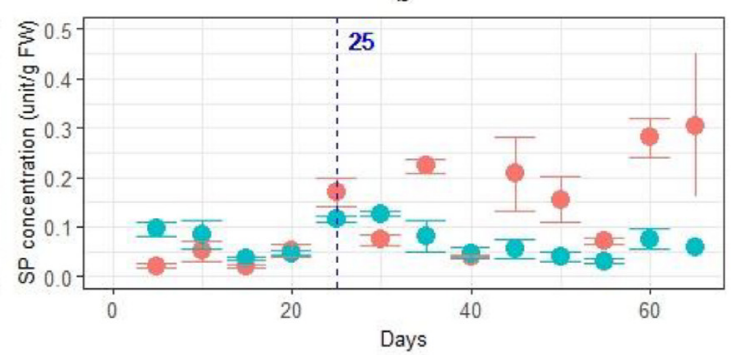

d

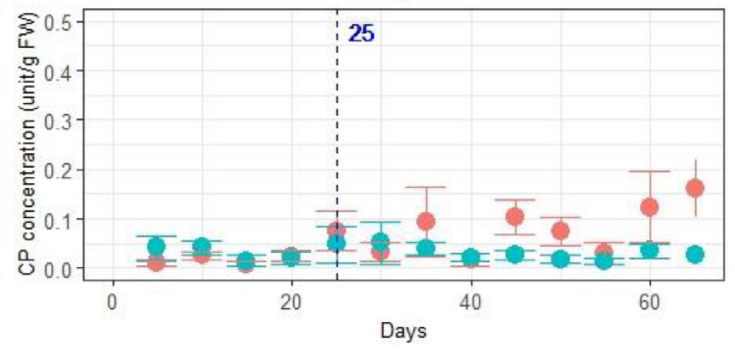

Position - Root Shoot

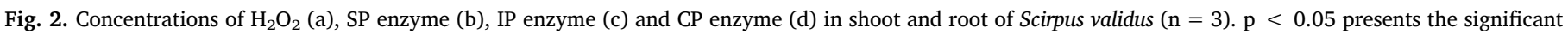
difference of enzymes concentration in shoot and root.

reducing ACT stress to plant. The root produced enzymes increasingly to degrade $\mathrm{H}_{2} \mathrm{O}_{2}$ and pollutants. The ACT concentration $(10 \mathrm{mg} / \mathrm{L})$ was substantial for the root; then it translocated part of ACT to the shoot (Huber et al., 2009). Among enzymes, their concentrations in plant ranged differently. Concentrations of SP enzyme reached to $0.3 \mathrm{unit} / \mathrm{g}$ FW while concentrations of IP enzyme expanded to 0.2 unit/g FW. For $\mathrm{CP}$ enzyme, the concentrations varied from 0.01 to $0.16 \mathrm{unit} / \mathrm{g} \mathrm{FW}$. We speculated that the concentration of SP enzyme was higher than the others because it presented in plant cell as a soluble form. Hence, it was more dynamic than the bound enzymes such as IP and CP.

The hydroxyl radical group is the most striking agent that breaks the aromatic structure of ACT, compared with $\mathrm{CO}_{3}{ }^{-}, \mathrm{ClO}^{-}$and ferrate (VI) (Phong Vo et al., 2019). It targets the ACT molecules by the normal and ipso mechanisms, following by a series of oxidation processes. Thus, it liberates the ring core and cleaves the phenol-acetamido bond (Fig. 3).

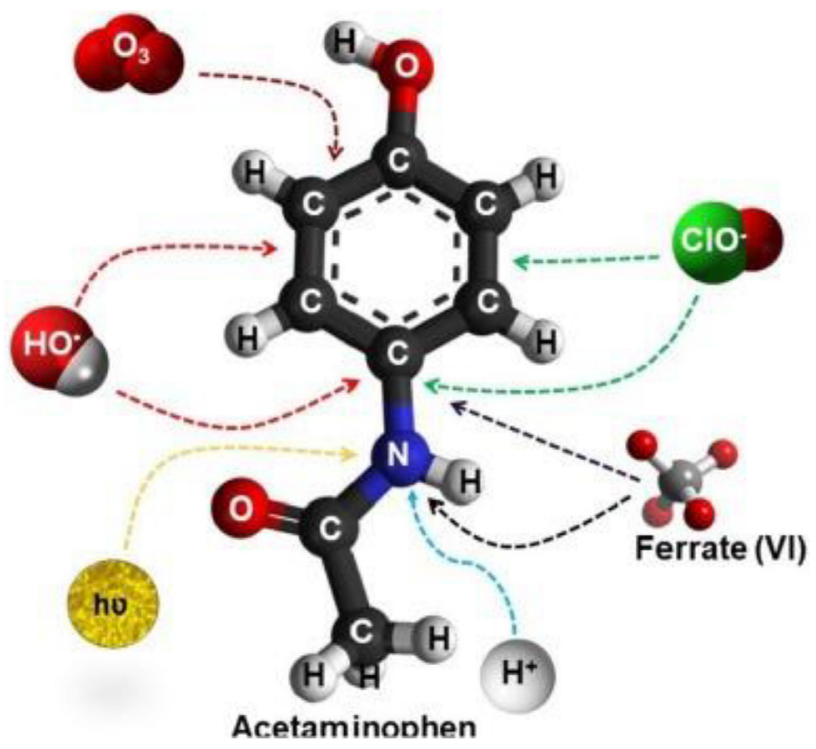

Fig. 3. Oxidative agents strike on bonding of ACT molecule. Retrieved from Phong Vo et al. (2019).
However, the hydroxyl radical group catalyzed by enzymes prefers invading the acetamido moiety than the aromatic ring (Phong Vo et al., 2019). Accordingly, the phenol-acetamido bond was hydrolyzed to form p-aminophenol and acetic acid. Afterward, $p$-aminophenol was oxidized by the $\mathrm{OH}$ radicals forming numerous by-products.

For plant, the documented mechanism was also to form hydroxylated intermediates, glucose conjugate, cysteine conjugate of micropollutants (Huber et al., 2009, 2012). Peroxidase was oxidized by two electrons of $\mathrm{H}_{2} \mathrm{O}_{2}$ creating intermediates. The intermediates continually oxidized micro-pollutants to metabolites. Then the intermediates were reduced back to peroxidase enzyme (Zhang and Geißen, 2010). Based on those evidences, we proposed the ACT degradation mechanism in plant expressed as below:

$$
\begin{aligned}
\mathrm{H}_{2} \mathrm{O}_{2}+\text { ACT } \stackrel{\text { peroxidase }}{\rightarrow} & \mathrm{N}-\text { acetyl }-1,4-\text { benzoquinone imine } \\
& +3-\text { hydroxyl }- \text { acetaminophen }+ \text { aceta } \min \text { ophen } \\
& - \text { glu cos ide }+ \text { acetaminophen }- \text { glutathione } \\
& + \text { cysteine conjugate }+\mathrm{H}_{2} \mathrm{O}
\end{aligned}
$$

Among the by-products, N-acetyl-1,4-benzoquinone imine was a toxic one. It was detoxified by glutathione S-transferase pi 1 enzyme or reduced to ACT by NAD(P)H dehydrogenase enzyme (Hwang et al., 2015). Other by-products are non-toxic.

Micro-pollutants uptaken by the plant were reported previously; however, the mechanism of the enzymes in detoxification remains unclear. Up to date, enzymes occupied two functions: catalysts and oxidizers. Some enzymes could break down the aromatic structures, esters and nitrile bonds of micro-pollutants' molecules (Ufarté et al., 2015). Examples are laccase and glycosyltransferase enzymes. In cucumber plant, glycosyltransferase enzyme could oxidize ACT (Bartha et al., 2014). Some peroxidase enzymes, such as horseradish and lignin peroxidase, degrade diclofenac to diclofenac-2,5-Iminoquinone by catalysing $\mathrm{H}_{2} \mathrm{O}_{2}$ (Huber et al., 2016). Still, peroxidase enzymes removed pesticide 2,4-dichlorophenol (Agostini et al., 2003). This study remains inconclusive as to whether the peroxidase enzymes could oxidize ACT directly. The detail mechanism still challenging and needed in-depth researches. 
Table 3

Relative importance of variables in ACT, COD, TN and TP equations.

\begin{tabular}{|c|c|c|c|c|c|c|c|c|c|}
\hline Relative importance (\%) & $\mathrm{C}_{\mathrm{H} 2 \mathrm{O} 2 . \mathrm{R}}$ & $\mathrm{C}_{\mathrm{H} 2 \mathrm{O} 2 . \mathrm{s}}$ & $\mathrm{C}_{\mathrm{SP} . \mathrm{R}}$ & $\mathrm{C}_{\mathrm{SP} . \mathrm{S}}$ & $\mathrm{C}_{\mathrm{CP} . \mathrm{R}}$ & $\mathrm{C}_{\mathrm{CP} . \mathrm{S}}$ & $\mathrm{C}_{\mathrm{IP} . \mathrm{R}}$ & $\mathrm{C}_{\mathrm{IP} . \mathrm{S}}$ & Total $\mathrm{R}^{2}$ \\
\hline ACT.E & 5.9 & 4.2 & 14.3 & 23.7 & 6.1 & 15.7 & 3.4 & 6.1 & 79.4 \\
\hline COD.E & 3.0 & 1.0 & 4.0 & 16.5 & 7.3 & 3.3 & 0.9 & 7.9 & 43.9 \\
\hline $\mathrm{NO}_{3}{ }^{-}$-N.E & 2.5 & 1.6 & 1.4 & 23.7 & 3.3 & 3.1 & 15.8 & 0.1 & 52.5 \\
\hline TP.E & 4.8 & 2.4 & 0.1 & 10.4 & 1.0 & 3.4 & 1.6 & 18.6 & 42.9 \\
\hline
\end{tabular}

Bold is the picked variables for constructing models.

\subsection{Correlations of enzymes and pollutants concentrations in CW effluent}

The effluent concentrations of ACT, $\mathrm{COD}, \mathrm{NO}_{3}{ }^{-}-\mathrm{N}$ and TP were modelled following the enzymes concentrations. Firstly, the $\mathrm{R}^{2}$ values of those models were calculated via Lindeman, Merenda and Gold's analysis (Table 3). The significant model should have $\mathrm{R}^{2}$ values higher than $50 \%$. Accordingly, the $\mathrm{R}^{2}$ values of $\mathrm{COD}, \mathrm{NO}_{3}{ }^{-}-\mathrm{N}$ and TP models were $40-50 \%$ and they were insignificant for establishing models. The $\mathrm{R}^{2}$ value of ACT model was around $80 \%$ that would be satisfactorily significant. For this ACT model, the Lindeman, Merenda and Gold analysis demonstrated that SP enzyme in the shoot and root and CP enzyme in the shoot contributed dominantly in the total $\mathrm{R}^{2}$. Each of those variables contributed at least $15 \%$. Other variables joined below $10 \%$ and would not be picked for constructing the model.

After determining the significant variables, the concentrations of ACT in effluent were modelled by three multivariable regression methods of "all possible subsets", "forward selection" and "backward elimination". As a result, only three variables were picked so that those methods exhibited similar outcomes (Eq. (8)).

$\mathrm{C}_{\text {ACT.E }}=0.089-1.744 * \mathrm{C}_{\text {SP.R }}+9.802 * \mathrm{C}_{\text {SP.S }}-84.487 * \mathrm{C}_{\text {CP.S }}$

$\left(R^{2}=68.3 \%, P=0.01, F=6.46>3\right)$

Comparing the coefficiencies of Eq. (8), the CP enzyme likely react the most actively in ACT removal, rather than the SP enzyme. One unit change in CP enzyme concentration was 10 to 50 -fold larger than SP enzyme. Although the SP enzyme was generated more than the $\mathrm{CP}$, its reactivity against ACT was much less. Depending on the interaction with cell wall, peroxidase enzymes presented as soluble, ionically bound and covalently bound. Those peroxidase enzymes reacted to organic compounds selectively (Kärkönen and Kuchitsu, 2015). For example, coniferyl and p-coumaryl alcohols could be oxidized by both anionic and cationic peroxidase enzyme while sinapyl alcohols was oxidized a subgroup of cationic peroxidase enzyme (Martínez-Rubio et al., 2018). Certain peroxidase enzymes could oxidize selective organic compounds thanks to steric hindrances at the substrates' binding site. For this case, IP enzyme was probably not a catalyst for ACT degradation.

The characteristic of soluble peroxidase on ACT degradation is clear; however, the one of ionical and covalent peroxidase is still on debate as those two peroxidase enzymes bind on cell wall similarly. Recent finding indicates the biochemical function of ionical and covalent peroxidase differ. Several reasons explain for their difference but the two important ones including: molecular mass of enzyme and affinity to $\mathrm{H}_{2} \mathrm{O}_{2}$ (Hadzi-Taskovic Sukalovic et al., 2015). For molecular mass, the value of ionical peroxidase marks $45 \mathrm{kDa}$ while the one of covalent peroxidase ranges $30,40,45$ and $50 \mathrm{kDa}$. The fluctuating molecules size of covalent peroxidase constitutes a complex structure between ACT and cell wall. Also, covalent peroxidase attracts $\mathrm{H}_{2} \mathrm{O}_{2}$ more than ionical peroxidase which can lead to the more ACT degradation efficiency. The covalent binding of covalent peroxidase increases affinity to $\mathrm{H}_{2} \mathrm{O}_{2}$ and conditions $\mathrm{H}_{2} \mathrm{O}_{2}$ participating in the degradation cycle (Eqs. (1)-(3)). For those reasons, covalent peroxidase is more preferable involving in ACT degradation, together soluble peroxidase, rather than ionical peroxidase.

\section{Practical applications}

This work exhibits the advance of vertical flow CW and peroxidase enzymes for hospital wastewater removal and tracking. Those results tailor the practical applications in developing countries. For those countries, CWs are prerequisite to reduce economic burden as capital and operation costs are low. Capital cost for CW varies from 82 to 225 $\mathrm{USD} / \mathrm{m}^{3}$ wastewater, whereas it takes $246-657 \mathrm{USD} / \mathrm{m}^{3}$ wastewater for a conventional treatment plant (Zhang et al., 2014b). In Vietnam, land is spacious that suitable for a low-cost CW treatment system. It is feasible for hospital wastewater treatment in Ho Chi Minh city - Vietnam and suburban regions (Nguyen et al., 2019). The CWs can be co-functioned as wastewater treatment system and landscape decoration to increase green space and cut off capital cost, like the butterfly CW in Thailand (Brix et al., 2011). Not only for treating hospital wastewater, vertical flow CW is also useful for removing other micro-pollutants wastewater such as industrial, agricultural and aquaculture wastewater. The vertical flow CW can tolerate to high-dose micro-pollutants. Effluent would comply with wastewater discharge standards in Thailand and Vietnam. For the case, shrimp farm wastewater with antibiotics (Can Gio, Vietnam) is a viable target for vertical flow CW (Pham et al., 2018). In industrial and cattle wastewater, it contains nutrient and micro-pollutants in urine and faeces that also effectively removed and recovered $80 \% \mathrm{~N}$ by CW (Libralato et al., 2012).

Monitoring micro-pollutants is costly and using enzymes is an alternative for developing countries. One micro-pollutants sample costs at least hundred US dollar (Testamerica Laboratories, 2015) whereas analysing enzymes by regular chemicals is much cheaper. The micropollutants analysis requires facilities and skill to develop standard methods. In turn, enzyme analysis only needs spectrophotometer and standard chemicals. To deploy the concept in practice, more micropollutants and enzymes, such as laccase, superoxide dismutase, need indepth studies.

\section{Conclusion}

The vertical flow CW effectively removed ACT and nutrients from hospital wastewater treatment. The peroxidase enzymes of $S$. validus planted in CW were feasible for monitoring ACT. It could track ACT concentration in the CW effluent for pollution control. This novel concept helped to reduce an extensive cost of micro-pollutants analytical facilities. Thus, for full-scale application, the studied data is a reference for designing micropollutants phyto-remediation process and monitoring. Similar micro-pollutants can be monitored by different plant species and enzymes. Still, the mechanism of the enzyme and micropollutants' reaction needs in-depth studies.

\section{Acknowledgements}

Authors would like to acknowledge Korea Institute of Science and Technology (KIST), Republic of Korea for financial assistance; Mahidol University (MU) for their laboratory support, and Thammasat University hospital, Thailand for providing wastewater. The support of NATS lab staff is duly appreciated. 


\section{Appendix A. Supplementary data}

Supplementary data to this article can be found online at https:// doi.org/10.1016/j.jenvman.2019.109526.

\section{References}

Agostini, E., Coniglio, M.S., Milrad, S.R., Tigier, H.A., Giulietti, A.M., 2003. Phytoremediation of 2,4-dichlorophenol by Brassica napus hairy root cultures. Biotechnol. Appl. Biochem. 37 (2), 139-144.

Alvarino, T., Suarez, S., Lema, J.M., Omil, F., 2014. Understanding the removal mechanisms of PPCPs and the influence of main technological parameters in anaerobic UASB and aerobic CAS reactors. J. Hazard. Mater. 278, 506-513.

APHA, 2005. Standard Methods for the Examination of Water and Wastewater, twentyfirst ed. American Public Health Association, Washington, DC.

Arias, M.E., Brown, M.T., 2009. Feasibility of using constructed treatment wetlands for municipal wastewater treatment in the Bogotá Savannah, Colombia. Ecol. Eng. 35 (7), 1070-1078.

Ávila, C., Reyes, C., Bayona, J.M., García, J., 2013. Emerging organic contaminant removal depending on primary treatment and operational strategy in horizontal subsurface flow constructed wetlands: influence of redox. Water Res. 47 (1), 315-325.

Ávila, C., Nivala, J., Olsson, L., Kassa, K., Headley, T., Mueller, R.A., Bayona, J.M., García, J., 2014. Emerging organic contaminants in vertical subsurface flow constructed wetlands: influence of media size, loading frequency and use of active aeration. Sci. Total Environ. 494-495, 211-217.

Ávila, C., Pelissari, C., Sezerino, P.H., Sgroi, M., Roccaro, P., García, J., 2017. Enhancement of total nitrogen removal through effluent recirculation and fate of PPCPs in a hybrid constructed wetland system treating urban wastewater. Sci. Total Environ. 584-585, 414-425.

Baratpour, P., Moussavi, G., 2018. The accelerated biodegradation and mineralization of acetaminophen in the $\mathrm{H}_{2} \mathrm{O}_{2}$-stimulated upflow fixed-bed bioreactor (UFBR). Chemosphere 210, 1115-1123.

Bartha, B., Huber, C., Harpaintner, R., Schröder, P., 2010. Effects of acetaminophen in Brassica juncea L. Czern.: investigation of uptake, translocation, detoxification, and the induced defense pathways. Environ. Sci. Pollut. Res. 17 (9), 1553-1562.

Bartha, B., Huber, C., Schröder, P., 2014. Uptake and metabolism of diclofenac in Typha latifolia - how plants cope with human pharmaceutical pollution. Plant Sci. 227, $12-20$.

Brix, H., Koottatep, T., Fryd, O., Laugesen, C.H., 2011. The flower and the butterfly constructed wetland system at Koh Phi Phi-system design and lessons learned during implementation and operation. Ecol. Eng. 37 (5), 729-735.

Carraro, E., Bonetta, S., Bertino, C., Lorenzi, E., Bonetta, S., Gilli, G., 2016. Hospital ef fluents management: chemical, physical, microbiological risks and legislation in different countries. J. Environ. Manag. 168, 185-199.

Chen, Z.M., Chen, B., Zhou, J.B., Li, Z., Zhou, Y., Xi, X.R., Lin, C., Chen, G.Q., 2008. A vertical subsurface-flow constructed wetland in Beijing. Commun. Nonlinear Sci. 13 (9), 1986-1997.

Dordio, A.V., Duarte, C., Barreiros, M., Carvalho, A.J.P., Pinto, A.P., da Costa, C.T., 2009. Toxicity and removal efficiency of pharmaceutical metabolite clofibric acid by Typha spp. - potential use for phytoremediation? Bioresour. Technol. 100 (3), 1156-1161.

Gupta, D.K., Huang, H.G., Corpas, F.J., 2013. Lead tolerance in plants: strategies for phytoremediation. Environ. Sci. Pollut. Res. 20 (4), 2150-2161.

Hadzi-Taskovic Sukalovic, V., Vuletic, M., Markovic, K., Cvetic Antic, T., Vucinic, Z., 2015. Comparative biochemical characterization of peroxidases (class III) tightly bound to the maize root cell walls and modulation of the enzyme properties as a result of covalent binding. Protoplasma 252 (1), 335-343.

Hickey, A., Arnscheidt, J., Joyce, E., O'Toole, J., Galvin, G., O' Callaghan, M., Conroy, K., Killian, D., Shryane, T., Hughes, F., Walsh, K., Kavanagh, E., 2018. An assessment of the performance of municipal constructed wetlands in Ireland. J. Environ. Manag. 210, 263-272.

Huber, C., Bartha, B., Harpaintner, R., Schröder, P., 2009. Metabolism of acetaminophen (paracetamol) in plants-two independent pathways result in the formation of a glutathione and a glucose conjugate. Environ. Sci. Pollut. Res. 16 (2), 206.

Huber, C., Bartha, B., Schröder, P., 2012. Metabolism of diclofenac in plants - hydroxylation is followed by glucose conjugation. J. Hazard Mater. 243, 250-256.

Huber, C., Preis, M., Harvey, P.J., Grosse, S., Letzel, T., Schröder, P., 2016. Emerging pollutants and plants - metabolic activation of diclofenac by peroxidases. Chemosphere 146, 435-441.

Hwang, J.H., Kim, Y.H., Noh, J.R., Gang, G.T., Kim, K.S., Chung, H.K., Tadi, S., Yim, Y.H., Shong, M., Lee, C.H., 2015. The protective role of NAD(P)H:quinone oxidoreductase 1 on acetaminophen-induced liver injury is associated with prevention of adenosine triphosphate depletion and improvement of mitochondrial dysfunction. Arch. Toxicol. 89 (11), 2159-2166.

Jaskulak, M., Rorat, A., Grobelak, A., Kacprzak, M., 2018. Antioxidative enzymes and expression of rbcL gene as tools to monitor heavy metal-related stress in plants. J. Environ. Manag. 218, 71-78.

Kahl, S., Nivala, J., van Afferden, M., Müller, R.A., Reemtsma, T., 2017. Effect of design and operational conditions on the performance of subsurface flow treatment wetlands: emerging organic contaminants as indicators. Water Res. 125, 490-500.

Kärkönen, A., Kuchitsu, K., 2015. Reactive oxygen species in cell wall metabolism and development in plants. Phytochemistry 112, 22-32.

Kim, Y., Choi, K., Jung, J., Park, S., Kim, P.-G., Park, J., 2007. Aquatic toxicity of acetaminophen, carbamazepine, cimetidine, diltiazem and six major sulfonamides, and their potential ecological risks in Korea. Environ. Int. 33 (3), 370-375.
Kosma, C.I., Lambropoulou, D.A., Albanis, T.A., 2010. Occurrence and removal of PPCPs in municipal and hospital wastewaters in Greece. J. Hazard Mater. 179 (1-3), 804-817.

Kumar, R., Sarmah, A.K., Padhye, L.P., 2019. Fate of pharmaceuticals and personal care products in a wastewater treatment plant with parallel secondary wastewater treatment train. J. Environ. Manag. 233, 649-659.

Libralato, G., Volpi Ghirardini, A., Avezzù, F., 2012. To centralise or to decentralise: an overview of the most recent trends in wastewater treatment management. J. Environ. Manag. 94 (1), 61-68.

Lin, A.Y.-C., Tsai, Y.-T., 2009. Occurrence of pharmaceuticals in Taiwan's surface waters: impact of waste streams from hospitals and pharmaceutical production facilities. Sci. Total Environ. 407 (12), 3793-3802.

Lin, A.Y.-C., Lin, C.-A., Tung, H.-H., Chary, N.S., 2010. Potential for biodegradation and sorption of acetaminophen, caffeine, propranolol and acebutolol in lab-scale aqueous environments. J. Hazard Mater. 183 (1-3), 242-250.

Liu, D., Løkke, M.M., Leegaard Riis, A., Mortensen, K., Feilberg, A., 2014. Evaluation of clay aggregate biotrickling filters for treatment of gaseous emissions from intensive pig production. J. Environ. Manag. 136, 1-8.

Machado, A.I., Dordio, A., Fragoso, R., Leitão, A.E., Duarte, E., 2017. Furosemide removal in constructed wetlands: comparative efficiency of LECA and Cork granulates as support matrix. J. Environ. Manag. 203, 422-428.

Martínez-Rubio, R., Acebes, J.L., Encina, A., Kärkönen, A., 2018. Class III peroxidases in cellulose deficient cultured maize cells during cell wall remodeling. Physiol. Plant. 164 (1), 45-55.

MonRe Thailand, 2005. Building Effluent Standards. Ministry of Natural Resources and Environment, Thailand.

MonRe Vietnam, 2010. National Technical Regulation on Health Care Wastewater. Ministry of Natural Resource and Environment, Vietnam.

Nguyen, X.C., Chang, S.W., Nguyen, T.L., Ngo, H.H., Kumar, G., Banu, J.R., Vu, M.C., Le, H.S., Nguyen, D.D., 2018. A hybrid constructed wetland for organic-material and nutrient removal from sewage: process performance and multi-kinetic models. J. Environ. Manag. 222, 378-384.

Nguyen, T.-T., Bui, X.-T., Dang, B.-T., Ngo, H.-H., Jahng, D., Fujioka, T., Chen, S.-S., Dinh, Q.-T., Nguyen, C.-N., Nguyen, P.-T.-V., 2019. Effect of ciprofloxacin dosages on the performance of sponge membrane bioreactor treating hospital wastewater. Bioresour. Technol. 273, 573-580.

Nuel, M., Laurent, J., Bois, P., Heintz, D., Wanko, A., 2018. Seasonal and ageing effect on the behaviour of 86 drugs in a full-scale surface treatment wetland: removal efficiencies and distribution in plants and sediments. Sci. Total Environ. 615, 1099-1109.

Nunes, B., Pinto, G., Martins, L., Gonçalves, F., Antunes, S.C., 2014. Biochemical and standard toxic effects of acetaminophen on the macrophyte species Lemna minor and Lemna gibba. Environ. Sci. Pollut. Res. 21 (18), 10815-10822.

Ortiz de García, S., Pinto Pinto, G., García Encina, P., Irusta Mata, R., 2013. Consumption and occurrence of pharmaceutical and personal care products in the aquatic en vironment in Spain. Sci. Total Environ. 444, 451-465.

Petrie, B., Rood, S., Smith, B.D., Proctor, K., Youdan, J., Barden, R., Kasprzyk-Hordern, B., 2018. Biotic phase micropollutant distribution in horizontal sub-surface flow constructed wetlands. Sci. Total Environ. 630, 648-657.

Pham, T.T.H., Rossi, P., Dinh, H.D.K., Pham, N.T.A., Tran, P.A., Ho, T.T.K.M., Dinh, Q.T., De Alencastro, L.F., 2018. Analysis of antibiotic multi-resistant bacteria and resistance genes in the effluent of an intensive shrimp farm (Long An, Vietnam). J. Environ. Manag. 214, 149-156.

Phong, V.H.N., Koottatep, T., Chapagain, S.K., Panuvatvanich, A., Polprasert, C., Ahn, K.H., 2016. Removal of acetaminophen from wastewater by constructed wetlands with Scirpus validus. Environ. Eng. Res. 21 (2), 164-170.

Phong Vo, H.N., Le, G.K., Hong Nguyen, T.M., Bui, X.-T., Nguyen, K.H., Rene, E.R., Vo, T.D.H., Thanh Cao, N.-D., Mohan, R., 2019. Acetaminophen micropollutant: historical and current occurrences, toxicity, removal strategies and transformation pathways in different environments. Chemosphere 236, 124391.

Ranieri, E., Verlicchi, P., Young, T.M., 2011. Paracetamol removal in subsurface flow constructed wetlands. J. Hydrol. 404 (3), 130-135.

Sgroi, M., Pelissari, C., Roccaro, P., Sezerino, P.H., García, J., Vagliasindi, F.G.A., Ávila, C., 2018. Removal of organic carbon, nitrogen, emerging contaminants and fluorescing organic matter in different constructed wetland configurations. Chem. Eng. J. $332,619-627$.

Sun, C., Dudley, S., Trumble, J., Gan, J., 2018. Pharmaceutical and personal care products-induced stress symptoms and detoxification mechanisms in cucumber plants. Environ. Pollut. 234, 39-47.

Testamerica Laboratories, 2015. General services administration federal acquisition services (fas) authorized federal price list. Access: 28 April 2019. https://www. gsaadvantage.gov.

Ufarté, L., Laville, É., Duquesne, S., Potocki-Veronese, G., 2015. Metagenomics for the discovery of pollutant degrading enzymes. Biotechnol. Adv. 33 (8), 1845-1854.

Valipour, A., Hamnabard, N., Woo, K.-S., Ahn, Y.-H., 2014. Performance of high-rate constructed phytoremediation process with attached growth for domestic wastewater treatment: effect of high TDS and Cu. J. Environ. Manag. 145, 1-8.

Verlicchi, P., Galletti, A., Petrovic, M., Barceló, D., Al Aukidy, M., Zambello, E., 2013 Removal of selected pharmaceuticals from domestic wastewater in an activated sludge system followed by a horizontal subsurface flow bed - analysis of their respective contributions. Sci. Total Environ. 454-455, 411-425.

Vulliet, E., Cren-Olivé, C., 2011. Screening of pharmaceuticals and hormones at the regional scale, in surface and groundwaters intended to human consumption. Environ. Pollut. 159 (10), 2929-2934.

Vymazal, J., 2011. Plants used in constructed wetlands with horizontal subsurface flow: a review. Hydrobiologia 674 (1), 133-156. 
Vymazal, J., Dvořáková Březinová, T., Koželuh, M., Kule, L., 2017. Occurrence and removal of pharmaceuticals in four full-scale constructed wetlands in the Czech Republic - the first year of monitoring. Ecol. Eng. 98, 354-364.

Yamamoto, H., Nakamura, Y., Moriguchi, S., Nakamura, Y., Honda, Y., Tamura, I., Hirata, Y., Hayashi, A., Sekizawa, J., 2009. Persistence and partitioning of eight selected pharmaceuticals in the aquatic environment: laboratory photolysis, biodegradation, and sorption experiments. Water Res. 43 (2), 351-362.

Yi, X., Tran, N.H., Yin, T., He, Y., Gin, K.Y.-H., 2017. Removal of selected PPCPs, EDCs, and antibiotic resistance genes in landfill leachate by a full-scale constructed wetlands system. Water Res. 121, 46-60.

Zandalinas, S.I., Mittler, R., 2018. ROS-induced ROS release in plant and animal cells. Free Radical Biol. Med. 122, 21-27.
Zhang, Y., Geißen, S.-U., 2010. In vitro degradation of carbamazepine and diclofenac by crude lignin peroxidase. J. Hazard Mater. 176 (1), 1089-1092.

Zhang, D.Q., Gersberg, R.M., Hua, T., Zhu, J., Ng, W.J., Tan, S.K., 2013. Assessment of plant-driven uptake and translocation of clofibric acid by Scirpus validus. Environ. Sci. Pollut. Res. 20 (7), 4612-4620.

Zhang, D., Gersberg, R.M., Ng, W.J., Tan, S.K., 2014a. Removal of pharmaceuticals and personal care products in aquatic plant-based systems: a review. Environ. Pollut. 184, 620-639.

Zhang, D.Q., Jinadasa, K.B.S.N., Gersberg, R.M., Liu, Y., Ng, W.J., Tan, S.K., 2014b. Application of constructed wetlands for wastewater treatment in developing countries - a review of recent developments (2000-2013). J. Environ. Manag. 141 $116-131$. 